\title{
REMOVAL OF THE EFFECT OF POSTCOITAL UNILATERAL OVARIECTOMY ON EMBRYO SURVIVAL IN THE RAT WITH OESTRADIOL
}

\author{
N. B. HAYNES AND G. E. LAMMING \\ University of Nottingham School of Agriculture, Sutton Bonington, Loughborough, \\ Leicestershire
}

(Received 7th August 1970)

\begin{abstract}
Summary. Unilateral ovariectomy of mature female rats 62 to $88 \mathrm{hr}$ after copulation resulted in a significant reduction in embryo survival in the ipsilateral uterine horn when compared to the contralateral horn. The effect was not apparent when oestradiol-17 $\beta$ was injected into the ovarian site at the time of ovariectomy.
\end{abstract}

It has recently been reported that removal of one ovary after mating reduced embryonic survival in the ipsilateral uterine horn in rats (Lamming \& Little, 1968) and mice (Bruce, Renwick \& Finn, 1968). It was suggested that this might be due to removal of a local supply of oestrogen which is necessary for implantation (Little, Haynes \& Lamming, 1970). Furthermore, the Fallopian tube may be involved, since the effect is modified by salpingemphraxis (Little, Gray \& Lamming, 1969). The experiments did not, however, preclude the possibility that the effect was due to egg loss or surgical trauma. These considerations formed the basis of the following experiment. Twenty mature virgin female rats from the Sutton Bonington colony of Wistar origin were used and randomly divided into two groups. Rats were maintained in a temperature of $20 \pm 2^{\circ} \mathrm{C}$ and under a light regimen of $12 \mathrm{hr}$ light/12 hr dark. They were individually caged and all rats were given unrestricted access to water and a standard ration. Males of the same strain were caged overnight with the females and vaginal smears examined each morning for the presence of spermatozoa as an indication of mating. Unilateral ovariectomy and a contralateral sham operation were performed on each rat 62 to $88 \mathrm{hr}$ after mating. Anaesthesia was induced by ether and the ovaries were approached by lateral incision, the periovarian sac opened and corpora lutea counted visually. The right or left ovaries were removed from alternate rats within each group after tying off the ovarian arterial and venous branches and the Fallopian tube was left intact. One group was given an injection of $0.05 \mu \mathrm{g}$ oestradiol-17 $\beta$ in $0.05 \mu \mathrm{l}$ arachis oil into the fatty tissue as close to the entrance of the ipsilateral Fallopian tube as possible. The remaining group was given an injection of $0.05 \mu 1$ oil only at the same site.

The animals were killed on Day 18 of pregnancy and the number of viable foetuses in each horn was noted. The utero-tubal junction and Fallopian tube 
on the side of ovariectomy, together with the surrounding fatty tissue, were fixed and examined histologically for ovarian remnants.

The results are shown in Table 1. No ovarian remnants were found and there were no significant differences between numbers of corpora lutea at operation. Comparison of the number of foetuses in the ipsilateral and contralateral horns within the control group revealed a significantly lower number in the ipsilateral horn $(P<0.01)$. This difference was not apparent in the treated group when comparisons were made between foetal numbers in the ipsilateral and contralateral horns. The number of foetuses in the ipsilateral horn of the treated groups was also significantly higher than the number of foetuses in the ipsilateral horn of the control group $(P<0 \cdot 01)$.

TABLE 1

THE EFFECT OF UNILATERAL OVARIECTOMY ON EMBRYO SURVIVAL AT DAY 18 OF PREGNANGY IN GONTROL AND OESTROGEN-TREATED RATS

\begin{tabular}{l|c|c|c|c}
\hline & \multicolumn{2}{|c|}{ Control } & \multicolumn{2}{c}{ Oestrogen-treated } \\
\cline { 2 - 5 } & $\begin{array}{c}\text { Ipsilateral } \\
\text { horn }\end{array}$ & $\begin{array}{c}\text { Contralateral } \\
\text { horn }\end{array}$ & $\begin{array}{c}\text { Ipsilateral } \\
\text { horn }\end{array}$ & $\begin{array}{c}\text { Contralateral } \\
\text { horn }\end{array}$ \\
\hline $\begin{array}{l}\text { No. of uterine horns } \\
\text { No. of corpora lutea at operation } \\
\text { (mean } \pm \text { S.E.) }\end{array}$ & 10 & 10 & 10 & 10 \\
$\begin{array}{c}\text { No. of viable foetuses } \\
\text { (mean } \pm \text { S.E.) }\end{array}$ & $6.70 \pm 0.45$ & $6.50 \pm 0.40$ & $7.20 \pm 0.51$ & $7 \cdot 30 \pm 0.60$ \\
\hline
\end{tabular}

The effectiveness of local injection of oestrogen into the ovarian site just before implantation in preventing embryo loss may be interpreted as indicative of local oestrogen activity from the normal ovary at this time, possibly by way of the Fallopian tube. The procedure, however, may merely raise overall oestrogen levels by absorption into the systemic circulation. In fact, the trend towards a lower foetal survival and large standard error (due to absence of foetuses in four horns) in the contralateral horn of the treated group might be explained in terms of a raised systemic oestrogen level; the additive effect of this on a local oestrogen supply from the remaining ovary might result in a detrimental 'local' hormone ratio at that horn. Experiments involving systemic injection of graded doses of oestradiol are in progress in an attempt to distinguish between these possibilities.

Regardless of the mechanism, the results show that the deleterious effects of unilateral ovariectomy on embryo survival are not due to mechanical loss of ova or surgical trauma and establish that hormonal mechanisms are likely to be involved.

\section{REFERENCES}

Bruce, H. M., Renwick, A. G. C. \& Finn, C. A. (1968) Effect of post-coital unilateral ovariectomy on implantation in mice. Nature, Lond. 219, 733. 
Lamming, G. E. \& LrtrLe, S. L. (1968) Effects of post-coital unilateral ovariectomy on embryo survival in the rat. F. Physiol., Lond. 196, 14P.

Little, S. L., Gray, A. J. \& LAMming, G. E. (1969) Local effect of the ovary on the uterus of the rat. 7. Endocr. 43, xxxiii.

Little, S. L., Haynes, N. B. \& Lamming, G. E. (1970) The effect of post-coital unilateral ovariectomy on embryo survival in the rabbit. 7. Reprod. Fert. 21, 541. 